\title{
On the Emerging Role of the Taste Receptor Type 1 (T1R) Family of Nutrient-Sensors in the Musculoskeletal System
}

\author{
Shoichiro Kokabu ${ }^{1,2, *}$, Jonathan W. Lowery ${ }^{3,4}$, Takashi Toyono ${ }^{5}$, Tsuyoshi Sato ${ }^{1}$ and \\ Tetsuya Yoda ${ }^{1}$ \\ 1 Department of Oral and Maxillofacial Surgery, Faculty of Medicine, Saitama Medical University, \\ Moroyama-machi, Iruma-gun, Saitama 350-0495, Japan; tsato@saitama-med.ac.jp (T.S.); \\ yoda@saitama-med.ac.jp (T.Y.) \\ 2 Division of Molecular Signaling and Biochemistry, Department of Health Promotion, \\ Kyushu Dental University, Kokurakita-ku, Kitakyushu, Fukuoka 803-8580, Japan \\ 3 Division of Biomedical Science, Marian University College of Osteopathic Medicine, 3200 Cold Spring Rd., \\ Indianapolis, IN 46222, USA; jlowery@marian.edu \\ 4 Bone \& Mineral Research Group, Marian University College of Osteopathic Medicine, 3200 Cold Spring Rd., \\ Indianapolis, IN 46222, USA \\ 5 Division of Anatomy, Department of Health Promotion, Kyushu Dental University, Kokurakita-ku, \\ Kitakyushu, Fukuoka 803-8580, Japan; toyono@kyu-dent.ac.jp \\ * Correspondence: r14kokabu@kyu-dent.ac.jp; Tel.: +81-285-3048
}

Academic Editor: Yung Hou Wong

Received: 14 February 2017; Accepted: 13 March 2017; Published: 15 March 2017

\begin{abstract}
The special sense of taste guides and guards food intake and is essential for body maintenance. Salty and sour tastes are sensed via ion channels or gated ion channels while $G$ protein-coupled receptors (GPCRs) of the taste receptor type 1 (T1R) family sense sweet and umami tastes and GPCRs of the taste receptor type 2 (T2R) family sense bitter tastes. T1R and T2R receptors share similar downstream signaling pathways that result in the stimulation of phospholipase-C- $\beta 2$. The T1R family includes three members that form heterodimeric complexes to recognize either amino acids or sweet molecules such as glucose. Although these functions were originally described in gustatory tissue, T1R family members are expressed in numerous non-gustatory tissues and are now viewed as nutrient sensors that play important roles in monitoring global glucose and amino acid status. Here, we highlight emerging evidence detailing the function of T1R family members in the musculoskeletal system and review these findings in the context of the musculoskeletal diseases sarcopenia and osteoporosis, which are major public health problems among the elderly that affect locomotion, activities of daily living, and quality of life. These studies raise the possibility that T1R family member function may be modulated for therapeutic benefit.
\end{abstract}

Keywords: taste receptor; bone; skeletal muscle; sarcopenia; osteoporosis; T1R3; myogenesis; bone remodeling

\section{Introduction}

The special sense of taste acts as the guardian and guide for food intake and is essential for body maintenance [1]. The sensation of taste can be divided into five distinct qualities; salty, sour, bitter, sweet, and umami [2]. The sensation of bitter and sour tastes deters us from ingesting potential toxic substances and strong acids while sweet, umami, and salty tastes encourage us to eat foods containing carbohydrates, amino acids, and sodium, respectively [2]. Salty and sour tastes are transduced via ion channels or gated ion channels which are expressed in gustatory tissues and in a variety of 
non-gustatory tissues such as the kidney [3]. In contrast, sensing of the remaining tastes relies on two distinct families of G protein-coupled receptors (GPCRs) named the taste receptor type 1 (T1R) family, which senses sweet and umami, and the taste receptor type 2 (T2R) family, which senses bitter [4-8].

Although the T1R and T2R receptor families drive different taste sensations, they share similar downstream signaling pathways wherein receptors are coupled to a heterotrimeric $G$ protein consisting of $\alpha-, \beta-$ and $\gamma$-subunits. Activation of the T1R or T2R triggers the separation of the $\alpha$-subunit, which is commonly $\alpha$-gustducin, from the $\beta / \gamma$ subunits. Downstream events include stimulating phospholipase $C \beta 2$ (PLC $\beta 2$ ) and second messengers that consequently increase cytosolic $\mathrm{Ca}^{2+}$ levels to activate the transient receptor potential cation channel M5 (TRPM5) and induce membrane depolarization and action potential generation $[9,10]$.

The T1R family includes three members, T1R1, T1R2, and T1R3, which form heterodimeric complexes that exhibit differential recognition of ligands: T1R3 complexes with T1R1 to form the umami taste receptor, which responds to amino acids, while T1R3 complexes with T1R2 to form the sweet taste receptor, which responds to molecules such as glucose $[7-9,11]$. Although these functions were originally described in and most commonly assigned to gustatory tissue, the first indication that T1Rs and elements of the taste transduction cascade might exist outside of the mouth was more than 20 years ago when the expression of the taste signaling-associated G protein $\alpha$-gustducin was observed in brush cells of the stomach and intestine [12]. Subsequent studies have demonstrated the expression of and a functional role for T1R family members in a wide variety of tissues and cell types such the pancreatic $\beta$-cells [13], adipose tissue [14], heart [15], and central nervous system [16]. Thus, despite the name "taste receptor", these GPCRs are now viewed as "nutrient sensors" that play important roles in chemoreception to detect global glucose and amino acid status [17].

The function of T1R family members in several non-gustatory systems has been summarized previously [2,18]. However, we are particularly struck by several recent reports highlighting T1R family members in the musculoskeletal system [19-22] and wish to briefly review these findings in the context of the musculoskeletal diseases sarcopenia and osteoporosis, which are major public health problems among the elderly that affect locomotion, activities of daily living, and quality of life [23].

\section{Sarcopenia and the Role of the T1R Family in Myogenesis}

Sarcopenia is characterized by an age-related loss of skeletal muscle mass and a decline in muscle strength that compromises the health span [24]. The prevalence of sarcopenia is approximately $10 \%$ among adults aged 60 or older [25], resulting in a cost over US $\$ 18$ billion in 2001 alone [26]. Thus, there is an unmet and urgent need for strategies that will improve skeletal muscle mass and/or function in aging adults.

Satellite cells are skeletal muscle stem cells that provide a regenerative capacity for skeletal muscle. Aged skeletal muscle shows a profound regenerative impairment that contributes to physical incapacitation. Aged skeletal muscles fail to retain stem cell quiescence [27-29] and both the number and the functionality of muscle stem cells decline with aging [27-32]. The process of autophagy, which involves the degradation of long-lived proteins and damaged organelles in lysosomes, has been implicated in the aging of different model organisms [29,33-36]. Recent work indicates that autophagy maintains the multipotency of satellite cells by preventing senescence [37], indicating that the appropriate regulation of autophagy is required for the maintenance of skeletal muscle mass and function. This also raises the possibility that dysregulation of autophagy is involved in the pathogenesis of sarcopenia.

Differentiation of skeletal muscle fibers-myogenesis-is a complex and tightly regulated process involving the commitment of mesenchymal stem cells to the myogenic lineage, myoblast proliferation, and exit from the cell cycle. This multi-step process is orchestrated by a handful of genes encoding the myogenic regulatory factors (MRFs), which belong to the basic-helix-loop-helix (bHLH) transcription factor family and consist of Myf5, MyoD, MRF4, and Myogenin. Although genetic models have shown that MRFs display a certain degree of functional redundancy [38,39], Myf5 and MyoD are 
responsible for myoblast lineage commitment, regulating the formation, proliferation, and longevity of myoblasts; MRF4 and Myogenin instead play critical roles in the regulation of the final stage of differentiation [40-42].

We recently reported that MRFs regulate the expression of the bi-functional T1R family member T1R3: overexpression of MyoD and Myogenin induces murine T1R3 promoter activity and ChIP analysis demonstrated that MyoD and Myogenin bind to the endogenous murine T1R3 promoter region and increase mRNA levels of endogenous T1R3 in the murine mesenchymal stem cell line C3H10T1/2, which has myogenic potential [20]. Comparative and functional genomic results examining transcription factor binding sites (Table 1) raise the possibility that the cis-regulatory elements by which MRFs regulate T1R3 expression are conserved across species [20]. These observations are consistent with the fact that expression levels of T1R3 increase with myogenic differentiation of the murine myoblast cell line C2C12 and skeletal muscle cell lines [20]; unpublished data from our group indicates that T1R1 expression also correlates with advanced differentiation during myogenesis (data not shown). These findings are supported by the findings that T1R1 and T1R3 are endogenously expressed in the skeletal muscle tissue and that skeletal muscle cells of T1R3 knockout mice exhibit decreasing activity of mechanistic target of rapamycin complex 1 (MTORC1) and a higher frequency of autophagy [21,43], suggesting that T1R3 function is critical to detecting nutrient status since skeletal muscle is the main source of stored amino acid during times of amino acid deprivation [44]. For these reasons, we hypothesize that reduced signaling through T1R3 is involved in the pathogenesis of skeletal muscle diseases such as sarcopenia through improper regulation of autophagy.

Table 1. Transcription factor binding sites are conserved between $H$. sapiens and M. musculus promoter region. Common transcription factor binding sites upstream of T1R3 were identified using rVista 2.0 for H. sapiens and M. musculus [20].

\begin{tabular}{|c|c|c|c|}
\hline No. & Transcription Factor (Description) & No. & Transcription Factor (Description) \\
\hline 1 & AP2 (activator protein 2) & 22 & LXR \\
\hline 2 & $\mathrm{AP} 2 \alpha($ activator protein $2 \alpha)$ & 23 & MAZ \\
\hline 3 & AP4 (activator protein 4) & 24 & MYOD (myoblast determining factor) \\
\hline 4 & ATF4 (activating transcription factor 4 ) & 25 & MYOGENIN \\
\hline 5 & CEBP (CCAAT/enhancer binding protein) & 26 & NGFIC \\
\hline 6 & $\mathrm{CHCH}$ (Churchill) & 27 & $\mathrm{R}$ (Epstein-Barr virus transcription factor $\mathrm{R}$ ) \\
\hline 7 & $\mathrm{CP} 2$ & 28 & RFX (X-box binding protein RFX) \\
\hline 8 & CREB (cAMP-response element-binding protein) & 29 & SEF1 \\
\hline 9 & DEAF1 & 30 & SMAD \\
\hline 10 & E12 & 31 & SMAD4 \\
\hline 11 & E2A & 32 & SP1 \\
\hline 12 & $\mathrm{E} 2 \mathrm{~F}$ & 33 & SPZ1 \\
\hline 13 & E2F1 & 34 & SREBP1 \\
\hline 14 & EBOX & 35 & SRF (serum response factor) \\
\hline 15 & EGR & 36 & SRY (sex-determining region Y gene product) \\
\hline 16 & FOXO4 (fork head box O4) & 37 & STAF (Se-Cys tRNA gene transcription activating factor) \\
\hline 17 & HEB & 38 & STRA13 \\
\hline 18 & HEN1 & 39 & TEF1 \\
\hline 19 & HSF1 (heat shock factor 1) & 40 & $\mathrm{UF} 1 \mathrm{H} 3 \beta$ \\
\hline 20 & KROX & 41 & USF (upstream stimulating factor) \\
\hline 21 & LBP1 & 42 & ZID (zinc finger with interaction domain) \\
\hline
\end{tabular}

\section{Osteoporosis and the Role of the T1R Family in Postnatal Bone Remodeling}

Osteoporosis is a skeletal disease characterized by low bone mass and microarchitectural deterioration of bone tissue with a consequent increase in bone fragility and susceptibility to fracture [45]. In 2010, more than 10 million Americans over the age of 50 had osteoporosis, with another 43 million Americans at risk for the disease [46]. It is estimated that greater than 1.5 million fragility fractures occur each year, with an annual health care cost of at least US\$14 billion [47] and, by 2025, the health care expenditures for osteoporotic fractures will approach US\$25.3 billion. The pathogenesis of osteoporosis is complex, with numerous pathways implicated as playing a role in regulating bone mass [48]; that said, there is an urgent and unmet need to identify new treatment targets and strategies for improving bone mass and strength in the aging skeleton. 
The T1R family members T1R2 and T1R3, which heterodimerize to form the sweet taste receptor, were recently identified as playing a role in the regulation of postnatal bone mass. Global loss of either T1R2 or T1R3 expression leads to increased cortical bone mass and trabecular remodeling under high fat conditions with little to no change in glucose tolerance, insulin sensitivity and energy balance [19]. Reduced bone marrow adiposity was observed in these mice and, since bone-forming osteoblasts and marrow adipocytes are both derived from bone marrow stromal cell (BMSC)s, these authors postulated that T1R2 and/or T1R3 regulates cell fate determination in the bone marrow microenvironment. These findings may hold insight into human disease as the balance between adipocyte and osteoblast differentiation is disrupted in some conditions such that adipocyte differentiation is increased relative to osteoblast differentiation, leading to a reduction in bone mass, increased bone fragility, and an increased susceptibility to fracture [49]. The role of T1R family members in bone formation requires further examination through the BMSC-specific deletion of T1R2 and/or T1R3 mice; however, conditional alleles are not available at present. Furthermore, it is possible that T1R family members may regulate bone remodeling via additional mechanisms since bone resorption is markedly reduced and cortical bone mass is increased in T1R3 knockout mice under standard dietary conditions [49].

\section{Conclusions}

Recent evidence indicates that T1R family members participate in the regulation of numerous physiological processes in a wide variety of organ systems [18]. In this brief review, we highlighted the emerging evidence that T1R family members are members of the endogenous mechanisms that impact the musculoskeletal system (Figure 1). The studies discussed here raise the possibility that T1R family member function may be modulated for therapeutic benefit.

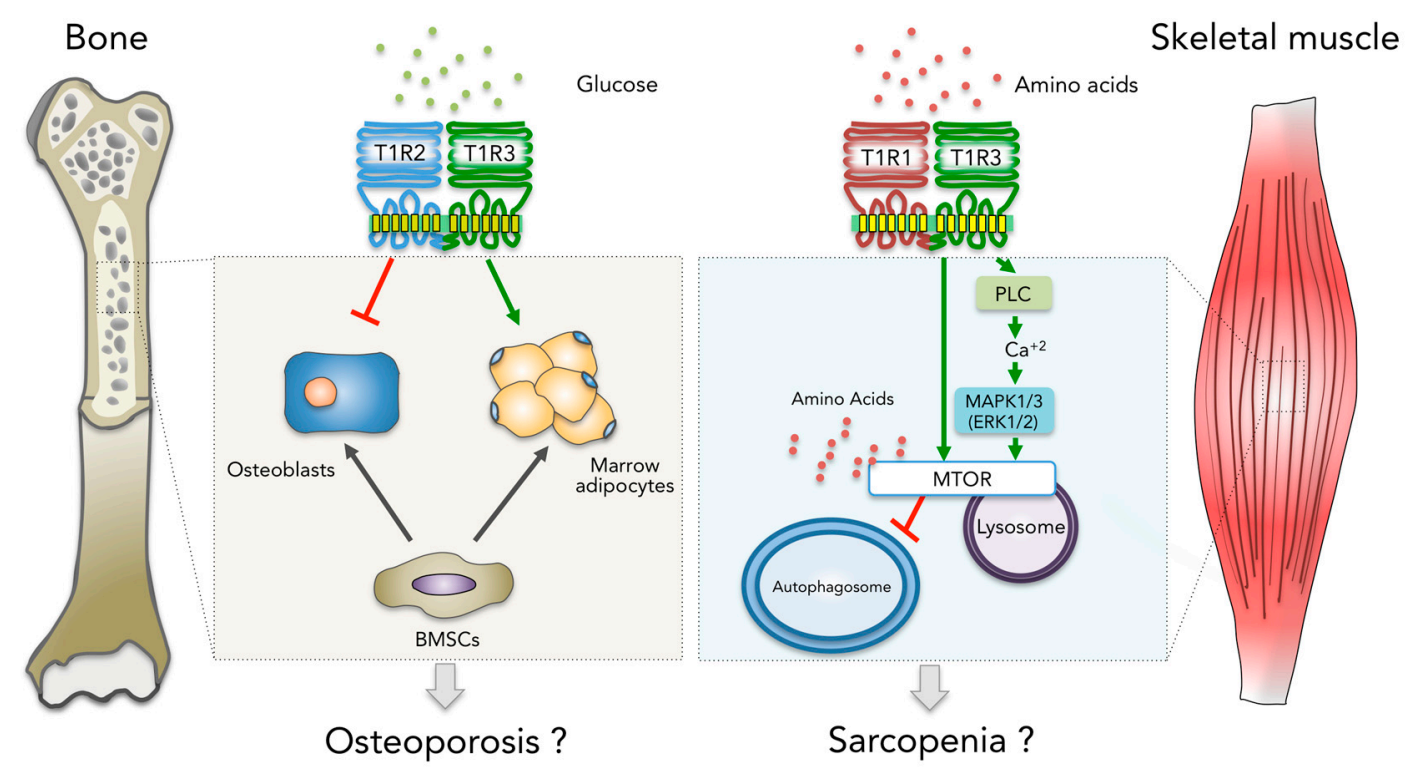

Figure 1. Model for the possible role of T1R family members in the bone marrow and skeletal muscle microenvironments. T1R2-T1R3 detects glucose and regulates cell fate determination of bone marrow stromal cells (BMSCs), promoting adipocyte (AD) differentiation over osteoblast (OB) differentiation. In contrast, T1R1-T1R3 detects amino acids leading to the activation of MTORC1 and inhibition of autophagy, in part through the activation of phospholipase C (PLC), increasing intracellular calcium and the activation of MAPK1-MAPK3. T1R1-T1R3 is required for the amino acid-induced localization of MTOR to the lysosome, which is a necessary step in MTORC1 activation [50].

Acknowledgments: All sources of funding of the study should be disclosed.

Author Contributions: All authors participated in the writing of the manuscript and approved the final version. 
Conflicts of Interest: The authors declare no conflicts of interest.

\section{References}

1. Loper, H.B.; La Sala, M.; Dotson, C.; Steinle, N. Taste perception, associated hormonal modulation, and nutrient intake. Nutr. Rev. 2015, 73, 83-91. [CrossRef] [PubMed]

2. Finger, T.E.; Kinnamon, S.C. Taste isn't just for taste buds anymore. F1000 Biol. Rep. 2011, 3, 20. [CrossRef] [PubMed]

3. Schild, L. The epithelial sodium channel and the control of sodium balance. BBA-Mol. Basis Dis. 2010, 1802, 1159-1165. [CrossRef] [PubMed]

4. Matsunami, H.; Montmayeur, J.P.; Buck, L.B. A family of candidate taste receptors in human and mouse. Nature 2000, 404, 601-604. [PubMed]

5. Hoon, M.A.; Adler, E.; Lindemeier, J.; Battey, J.F.; Ryba, N.J.; Zuker, C.S. Putative mammalian taste receptors: A class of taste-specific GPCRs with distinct topographic selectivity. Cell 1999, 96, 541-551. [CrossRef]

6. Adler, E.; Hoon, M.A.; Mueller, K.L.; Chandrashekar, J.; Ryba, N.J.; Zuker, C.S. A novel family of mammalian taste receptors. Cell 2000, 100, 693-702. [CrossRef]

7. Nelson, G.; Hoon, M.A.; Chandrashekar, J.; Zhang, Y.; Ryba, N.J.; Zuker, C.S. Mammalian sweet taste receptors. Cell 2001, 106, 381-390. [CrossRef]

8. Nelson, G.; Chandrashekar, J.; Hoon, M.A.; Feng, L.; Zhao, G.; Ryba, N.J.; Zuker, C.S. An amino-acid taste receptor. Nature 2002, 416, 199-202. [CrossRef] [PubMed]

9. Zhao, G.Q.; Zhang, Y.; Hoon, M.A.; Chandrashekar, J.; Erlenbach, I.; Ryba, N.J.; Zuker, C.S. The receptors for mammalian sweet and umami taste. Cell 2003, 115, 255-266. [CrossRef]

10. Andres-Barquin, P.J.; Conte, C. Molecular basis of bitter taste: The T2R family of G protein-coupled receptors. Cell Biochem. Biophys. 2004, 41, 99-112. [CrossRef]

11. Li, X.; Staszewski, L.; Xu, H.; Durick, K.; Zoller, M.; Adler, E. Human receptors for sweet and umami taste. Proc. Natl. Acad. Sci. USA 2002, 99, 4692-4696. [CrossRef] [PubMed]

12. Hofer, D.; Puschel, B.; Drenckhahn, D. Taste receptor-like cells in the rat gut identified by expression of

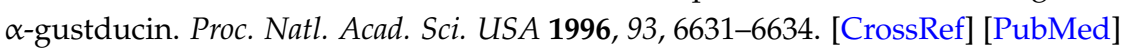

13. Oya, M.; Suzuki, H.; Watanabe, Y.; Sato, M.; Tsuboi, T. Amino acid taste receptor regulates insulin secretion in pancreatic $\beta$-cell line min6 cells. Genes Cells 2011, 16, 608-616. [CrossRef] [PubMed]

14. Masubuchi, Y.; Nakagawa, Y.; Ma, J.; Sasaki, T.; Kitamura, T.; Yamamoto, Y.; Kurose, H.; Kojima, I.; Shibata, H. A novel regulatory function of sweet taste-sensing receptor in adipogenic differentiation of 3T3-L1 cells. PLoS ONE 2013, 8, e54500. [CrossRef] [PubMed]

15. Foster, S.R.; Porrello, E.R.; Purdue, B.; Chan, H.W.; Voigt, A.; Frenzel, S.; Hannan, R.D.; Moritz, K.M.; Simmons, D.G.; Molenaar, P.; et al. Expression, regulation and putative nutrient-sensing function of taste GPCRs in the heart. PLoS ONE 2013, 8, e64579. [CrossRef] [PubMed]

16. Ren, X.; Zhou, L.; Terwilliger, R.; Newton, S.S.; De Araujo, I.E. Sweet taste signaling functions as a hypothalamic glucose sensor. Front. Integr. Neurosci. 2009, 3, 12. [CrossRef] [PubMed]

17. Miyamoto, T.; Wright, G.; Amrein, H. Nutrient sensors. Curr. Biol. 2013, 23, R369-R373. [CrossRef] [PubMed]

18. Laffitte, A.; Neiers, F.; Briand, L. Functional roles of the sweet taste receptor in oral and extraoral tissues. Curr. Opin. Clin. Nutr. Metab. Care 2014, 17, 379-385. [CrossRef] [PubMed]

19. Simon, B.R.; Learman, B.S.; Parlee, S.D.; Scheller, E.L.; Mori, H.; Cawthorn, W.P.; Ning, X.; Krishnan, V.; Ma, Y.L.; Tyrberg, B.; et al. Sweet taste receptor deficient mice have decreased adiposity and increased bone mass. PLoS ONE 2014, 9, e86454. [CrossRef] [PubMed]

20. Kokabu, S.; Lowery, J.W.; Toyono, T.; Seta, Y.; Hitomi, S.; Sato, T.; Enoki, Y.; Okubo, M.; Fukushima, Y.; Yoda, T. Muscle regulatory factors regulate T1R3 taste receptor expression. Biochem. Biophys. Res. Commun. 2015, 468, 568-573. [CrossRef] [PubMed]

21. Wauson, E.M.; Zaganjor, E.; Lee, A.Y.; Guerra, M.L.; Ghosh, A.B.; Bookout, A.L.; Chambers, C.P.; Jivan, A.; McGlynn, K.; Hutchison, M.R.; et al. The G protein-coupled taste receptor T1R1/T1R3 regulates mTORC1 and autophagy. Mol. Cell 2012, 47, 851-862. [CrossRef] [PubMed]

22. Eaton, M.S.; Newby, J.B.; Plattes, M.; Foster, H.; Wauson, E.M.; Dewar, B.; Arthur, J.; Lowery, J.W. Loss of the nutrient sensor Tas1R3 leads to reduced bone resorption. In Proceedings of the American Society for Bone and Mineral Research Annual Meeting, Seattle, WA, USA, 9-12 October 2015. 
23. Yoshimura, N.; Nakamura, K. Epidemiology of locomotive organ disorders and symptoms: An estimation using the population-based cohorts in japan. Clinical Rev. Bone Miner. Metab. 2016, 14, 68-73. [CrossRef] [PubMed]

24. Delmonico, M.J.; Harris, T.B.; Lee, J.S.; Visser, M.; Nevitt, M.; Kritchevsky, S.B.; Tylavsky, F.A.; Newman, A.B.; Health, A.; Body Composition, S. Alternative definitions of sarcopenia, lower extremity performance, and functional impairment with aging in older men and women. J. Am. Geriatr. Soc. 2007, 55, 769-774. [CrossRef] [PubMed]

25. Cruz-Jentoft, A.J.; Baeyens, J.P.; Bauer, J.M.; Boirie, Y.; Cederholm, T.; Landi, F.; Martin, F.C.; Michel, J.P.; Rolland, Y.; Schneider, S.M.; et al. Sarcopenia: European consensus on definition and diagnosis: Report of the european working group on sarcopenia in older people. Age Ageing 2010, 39, 412-423. [CrossRef] [PubMed]

26. Janssen, I.; Shepard, D.S.; Katzmarzyk, P.T.; Roubenoff, R. The healthcare costs of sarcopenia in the united states. J Am. Geriatr. Soc. 2004, 52, 80-85. [CrossRef] [PubMed]

27. Chakkalakal, J.V.; Jones, K.M.; Basson, M.A.; Brack, A.S. The aged niche disrupts muscle stem cell quiescence. Nature 2012, 490, 355-360. [CrossRef] [PubMed]

28. Sousa-Victor, P.; Gutarra, S.; Garcia-Prat, L.; Rodriguez-Ubreva, J.; Ortet, L.; Ruiz-Bonilla, V.; Jardi, M.; Ballestar, E.; Gonzalez, S.; Serrano, A.L.; et al. Geriatric muscle stem cells switch reversible quiescence into senescence. Nature 2014, 506, 316-321. [CrossRef] [PubMed]

29. Sousa-Victor, P.; Garcia-Prat, L.; Serrano, A.L.; Perdiguero, E.; Munoz-Canoves, P. Muscle stem cell aging: Regulation and rejuvenation. Trends. Endocrinol. Metab. 2015, 26, 287-296. [CrossRef] [PubMed]

30. Price, F.D.; von Maltzahn, J.; Bentzinger, C.F.; Dumont, N.A.; Yin, H.; Chang, N.C.; Wilson, D.H.; Frenette, J.; Rudnicki, M.A. Inhibition of jak-stat signaling stimulates adult satellite cell function. Nat. Med. 2014, 20, 1174-1181. [CrossRef] [PubMed]

31. Tierney, M.T.; Aydogdu, T.; Sala, D.; Malecova, B.; Gatto, S.; Puri, P.L.; Latella, L.; Sacco, A. STAT3 signaling controls satellite cell expansion and skeletal muscle repair. Nat. Med. 2014, 20, 1182-1186. [CrossRef] [PubMed]

32. Bernet, J.D.; Doles, J.D.; Hall, J.K.; Kelly Tanaka, K.; Carter, T.A.; Olwin, B.B. P38 MAPK signaling underlies a cell-autonomous loss of stem cell self-renewal in skeletal muscle of aged mice. Nat. Med. 2014, 20, 265-271. [CrossRef] [PubMed]

33. Cuervo, A.M.; Bergamini, E.; Brunk, U.T.; Droge, W.; Ffrench, M.; Terman, A. Autophagy and aging: The importance of maintaining "clean" cells. Autophagy 2005, 1, 131-140. [CrossRef] [PubMed]

34. He, C.; Klionsky, D.J. Regulation mechanisms and signaling pathways of autophagy. Annu. Rev. Genet. 2009, 43, 67-93. [CrossRef] [PubMed]

35. Carnio, S.; LoVerso, F.; Baraibar, M.A.; Longa, E.; Khan, M.M.; Maffei, M.; Reischl, M.; Canepari, M.; Loefler, S.; Kern, H.; et al. Autophagy impairment in muscle induces neuromuscular junction degeneration and precocious aging. Cell Rep. 2014, 8, 1509-1521. [CrossRef] [PubMed]

36. Rubinsztein, D.C.; Marino, G.; Kroemer, G. Autophagy and aging. Cell 2011, 146, 682-695. [CrossRef] [PubMed]

37. Garcia-Prat, L.; Martinez-Vicente, M.; Perdiguero, E.; Ortet, L.; Rodriguez-Ubreva, J.; Rebollo, E.; Ruiz-Bonilla, V.; Gutarra, S.; Ballestar, E.; Serrano, A.L.; et al. Autophagy maintains stemness by preventing senescence. Nature 2016, 529, 37-42. [CrossRef] [PubMed]

38. Wang, Y.; Jaenisch, R. Myogenin can substitute for Myf5 in promoting myogenesis but less efficiently. Development 1997, 124, 2507-2513. [PubMed]

39. Zhu, Z.; Miller, J.B. Mrf4 can substitute for myogenin during early stages of myogenesis. Dev. Dyn. 1997, 209, 233-241. [CrossRef]

40. Lassar, A.B.; Skapek, S.X.; Novitch, B. Regulatory mechanisms that coordinate skeletal muscle differentiation and cell cycle withdrawal. Curr. Opin. Cell Biol. 1994, 6, 788-794. [CrossRef]

41. Pownall, M.E.; Gustafsson, M.K.; Emerson, C.P., Jr. Myogenic regulatory factors and the specification of muscle progenitors in vertebrate embryos. Annu. Rev. Cell Dev. Bi. 2002, 18, 747-783. [CrossRef] [PubMed]

42. Yun, K.; Wold, B. Skeletal muscle determination and differentiation: Story of a core regulatory network and its context. Curr. Opin. Cell Biol. 1996, 8, 877-889. [CrossRef]

43. Wauson, E.M.; Lorente-Rodriguez, A.; Cobb, M.H. Minireview: Nutrient sensing by G protein-coupled receptors. Mol. Endocrinol 2013, 27, 1188-1197. [CrossRef] [PubMed] 
44. Shimizu, N.; Yoshikawa, N.; Ito, N.; Maruyama, T.; Suzuki, Y.; Takeda, S.; Nakae, J.; Tagata, Y.; Nishitani, S.; Takehana, K.; et al. Crosstalk between glucocorticoid receptor and nutritional sensor mtor in skeletal muscle. Cell Metab. 2011, 13, 170-182. [CrossRef] [PubMed]

45. Edwards, M.H.; Dennison, E.M.; Aihie Sayer, A.; Fielding, R.; Cooper, C. Osteoporosis and sarcopenia in older age. Bone 2015, 80, 126-130. [CrossRef] [PubMed]

46. Wright, N.C.; Looker, A.C.; Saag, K.G.; Curtis, J.R.; Delzell, E.S.; Randall, S.; Dawson-Hughes, B. The recent prevalence of osteoporosis and low bone mass in the united states based on bone mineral density at the femoral neck or lumbar spine. J. Bone Miner. Res. 2014, 29, 2520-2526. [CrossRef] [PubMed]

47. Blume, S.W.; Curtis, J.R. Medical costs of osteoporosis in the elderly medicare population. Osteoporos. Int. 2011, 22, 1835-1844. [CrossRef] [PubMed]

48. Kokabu, S.; Tsuchiya-Hirata, S.; Fukushima, H.; Sugiyama, G.; Lowery, J.W.; Katagiri, T.; Jimi, E. Inhibition of bone morphogenetic protein-induced osteoblast differentiation. J.Oral. Biosci. 2015, 57, 179-184. [CrossRef]

49. Harvey, N.; Dennison, E.; Cooper, C. Osteoporosis: Impact on health and economics. Nat. Rev. Rheumatol. 2010, 6, 99-105. [CrossRef] [PubMed]

50. Wauson, E.M.; Zaganjor, E.; Cobb, M.H. Amino acid regulation of autophagy through the GPCR TAS1R1-TAS1R3. Autophagy 2013, 9, 418-419. [CrossRef] [PubMed]

(c) 2017 by the authors. Licensee MDPI, Basel, Switzerland. This article is an open access article distributed under the terms and conditions of the Creative Commons Attribution (CC BY) license (http:/ / creativecommons.org/licenses/by/4.0/). 